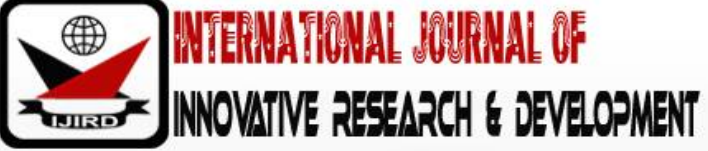

ISSN 2278 - 0211 (Online)

\section{Altering Students Misconceptions in Electrochemistry Using Conceptual Change Texts}

\author{
Philip Dorsah \\ Tutor, Department of Science, Gambaga College of Education, Ghana \\ Boniface Yaayin \\ Tutor, Department of Science Education, Tamale College of Education, Ghana
}

\begin{abstract}
:
The purpose of the study was to identify misconceptions that students have about electrochemistry concepts and how they can be altered using conceptual change texts. A quasi-experimental design was employed. Two intact classes were chosen from two schools for the study. One school was assigned the control group and the other the experimental group. The control group class was at Ghana Senior High School, in Tamale in the northern region of Ghana and the experimental group was at Damongo Senior High School, in Damongo in the Savannah region of Ghana. The results revealed that students have many misconceptions regarding electrochemistry concepts. Many of the misconceptions centered on identifying the anode and cathode of galvanic cells, Functions of the salt bridge, Direction of flow of ions in electrochemical cells and Reactions occurring at the cells. The results also showed that for both experimental and control groups no student had sound understanding of the electrochemistry concepts tested. The results showed that there exists significant difference between the percentages of misconceptions of students in the experimental and control groups after treatment. This suggested that conceptual change texts helped students to change their preexisting conceptions or misconceptions for scientifically acceptable ones. The study also revealed that some misconceptions were held by a considerable number of students even after the instruction using conceptual change texts. The most common misconceptions identified are; that the function of the salt bridge is to allow electron flow, the anode in an electrochemical cell is always on the left, in an electrochemical cell electrons move from one electrode to the other through the salt bridge, in an electrochemical cell anions move from anode to cathode, the cathode in an electrochemical cell is always on the right, and in an electrochemical cell oxidation occurs at the cathode and reduction at the anode.
\end{abstract}

Keywords: Misconception, conceptual change texts, electrochemistry

\section{Introduction}

Real understanding of chemistry demands the bringing together of conceptual understandings in a meaningful way. According to Johnstone and Bodnercited in Sirhan (2007), what is taught by teachers is not always what is learned by students. They added that while students show some evidence of learning and understanding in examination papers, research showed evidence of misconceptions and rote learning of certain areas of basic chemistry which are still not understood. Johnstone again indicated that the nature of chemistry concepts and the way the concepts are represented (macroscopic, microscopic, or representational) make chemistry difficult to learn.

Ozkaya (2002) attributes learning difficulties in electrochemistry to a general lack of conceptual understanding and attributes this to insufficient textbook explanations of these concepts. Research has shown that students have difficulties in conceptualizing redox reactions (Osterlund, 2009). According to Sirhan (2007), numerous reports supported the view that the interplay between macroscopic and microscopic worlds is a source of difficulty for many chemistry learners. Conceptual change points to the development and transformation of students understanding from their naive conceptions to scientific explanation (Uzuntiryaki, 2003).Conceptual change theory takes constructivism as its foundation, and addresses how thoughts must be altered in order to coincide with scientific theory (Meyers, 2007).The model has direct implications regarding how to construct instruction to achieve conceptual change (Read, 2004). Chemistry instruction should be designed to present anomalies so as to create cognitive conflict. This will create a disequilibrium, which leads to dissatisfaction with the existing concept, and ultimately to a willingness to accommodate a new concept. Teaching chemistry should therefore focus on providing students with opportunities in which they have cognitive conflict and develop different structures based on their experience. Conceptual change can be accomplished if students are given opportunity to be aware of their ideas, to encounter ideas other than their own and to realize the deficiency in their reasoning. According to Balci (2014), conceptual change texts are texts designed to change students' alternative conceptions and focus on strategies to promote conceptual change by challenging students' alternative conceptions, producing dissatisfaction, followed by a correct explanation which is both understandable and plausible to the students. 


\subsection{Purpose of the Study}

The purpose of this study was to use conceptual change texts to alter students' misconceptions about electrochemistry.

\subsection{Statement of the Problem}

The terms alternative conceptions and misconceptions have the same meaning that can be used to refer to students' conceptions that are different from scientifically accepted ones (Ozmen, 2007; Taber \& Tan, 2011). Students have many alternative conceptions regarding electrochemistry. This affects their understanding resulting in poor performance in chemistry.

\subsection{Hypotheses}

The following research hypothesis was tested:

- $\mathrm{H}_{0}$ : there is no significant difference in achievement between students taught with conceptual change texts and those taught with the traditional method.

- $\mathrm{H}_{1}$ : there is significant difference in achievement between students taught with conceptual change texts and those taught with the traditional method.

\subsection{Literature Review}

Electrochemistry is the study of the inter-conversion of electrical and chemical energies which involves many examples of chemical observations, chemical reactions and symbols. Electrochemistry has been widely reported as being one of the most difficult topics in chemistry because it contains many ambiguous and abstract terms (Sanger \& Greenbowe, 1997a \& 1997b; Ozmen, 2004; Schmidt et al., 2007).

Again, research indicated that electrochemistry is regarded as one of the most difficult chemistry concepts in which both pre-service teachers and students have learning difficulties (Ozkaya, 2002; Akram, BinSurif, \& Ali, 2014; Ndlovu, 2014). Huddle, White and Rogers (2000) found that a few students in their study had a coherent concept of the purpose of the salt-bridge. On redox reactions, they found that learners think that electrons are lost and thus reduction takes place. Garnett and Treagust (1992a) administered questions on concentration cells to introductory college students after electrochemistry teaching to determine misconceptions. The misconceptions include: the notion that water is not reactive in the electrolysis of aqueous solutions, students believed that electrons flow through the electrolyte and salt bridge to complete a circuit and the negative sign which are assigned to electrodes represent net electron charges. Students also had the notion that cell potentials are absolute and can be used to predict if the half-cell reactions are spontaneous or not and the cell potential are independent of ion concentrations (Ozmen, 2004).

Hamza and Wickman (2007) found that learners had misconception about the electrode processes as portrayed by one learner's response who said that "the anode should be positive because it loses electrons". Learners seem to think that the cathode is always on the right and the anode on the left. Linked to this misconception, many learners interpret a negative electrode to imply that the electrode is negatively charged. The report also indicated that learners struggle with questions that require the use of the Table of standard reduction potentials. Sanger and Greenbowe (1997) in a study found that many learners think that the first half cell is always the anode and the other is the cathode. Garnett and Treagust (1992a) concluded that students holding misconceptions about the way electricity is conducted in metallic conductors and electrolytes are highly unlikely to understand the operation of electrochemical cells. According to Schmidt, Marohn and Harrison cited in Taha (2014) students based their reasoning on four alternative concepts about electrochemistry;

- During electrolysis, the electric current produces ions;

- electrons migrate through the solution from one electrode to the other;

- the cathode is always the minus pole, the anode the plus pole; and

- The plus and minus poles carry charges.

Ndlovu also identified the following misconceptions about the salt bridge:

- Learners think that ions move through the salt bridge from the one half-cell to the other half-cell.

- Ions move from the salt bridge into the half-cells to ensure that no built-up of charge takes place at the electrodes.

- The salt bridge maintains neutrality of the cell (should be electrical neutrality);

- The salt bridge completes the cell / current (instead of completes the circuit);

- The salt bridge connects the half-cells

- The salt bridge transfer $\mathrm{Cu}^{2+}$ ions to $\mathrm{Pb}^{2+}$ ions and $\mathrm{Pb}^{2+}$ ions to $\mathrm{Cu}^{2+}$ ions

- The salt bridge allows ions to move from the anode to the cathode or from the cathode to the anode

- The salt bridge transfers electrons

- The salt bridge separates the two electrolytes and

- The salt bridge transports charge.

Huddle, White and Rogers (2000) also found that few students in their study had a coherent concept of the purpose of the salt-bridge. 


\section{Methodology}

\subsection{Research Design}

A quasi-experimental design was used for the study. A quasi-experiment is a type of experimental design in which the researcher has limited control over the selection of study participants (Levy \& Ellis, 2011). The study utilized anonequivalent pretest-posttest control group design. According to Campbell \& Stanley cited Levy and Ellis (2011), the pretestposttest with control group design is the most commonly used due to its recognized strength in controlling threats to internal validity. The researcher randomly assigns participants or events to two groups. The experimental group undergoes the prescribe treatment, while the second, the control group is the group that receives no treatment at all and serves as the benchmarking point of comparison.

Two intact classes were chosen from two schools for the study. One school was assigned the control group and the other the experimental group. The control group class was at Ghana Senior High School, in Tamale and the experimental group was at Damongo Senior High School. Damongo is about $124 \mathrm{~km}$ South-West of Tamale, the capital of Northern Region.

Both schools have similar characteristics such as population, infrastructure and characteristics of students. The different location of the control group and experimental group was envisioned to avoid threats to internal validity of the study such as interaction and diffusion of treatment between control group and experimental group. Each group was given a pre-test before and a post-test after the interventions. The research design is as follows:

\begin{tabular}{|c|c|c|c|}
\hline Groups & Pre-Test & Treatment & Post-Test \\
\hline Experimental Group(EG) & ECCT, ATECS & $\mathrm{X}_{1}$ & ECCT, ATECS \\
\hline Control Group(CG) & ECCT, ATECS & $\mathrm{X}_{2}$ & ECCT, ATECS \\
\hline
\end{tabular}

Table 1: Research Design Showing Groups, Tests, Intervention and Instruments

EG represents the experimental group that was taught using Conceptual Change Texts $\left(\mathrm{X}_{1}\right)$ and CG represents the control group that was taught by the traditional teacher-centered approach $\left(\mathrm{X}_{2}\right)$. ECCT is electrochemistry concept test and ATECS is attitude toward electrochemistry scale.

\subsection{Instrument}

In order to assess students understanding of electrochemistry concepts, the electrochemistry concept test (ECCT) was developed by the researchers. The ECCT consisted of 20 multiple choice test items.

The construction of the items was guided by the instructional objectives associated with electrochemistry in the national curriculum. Some of the objectives are presented in Table 2.

\begin{tabular}{|ll|}
\hline \multicolumn{1}{|c|}{ The Student Will Be Able To } \\
\hline 1. & Describe Oxidation and Reduction Processes. \\
\hline 2. & Describe an experiment to illustrate reactivity of metals. \\
\hline 3. & Describe oxidizing and reducing agents. \\
\hline 4. & Explain the steps involved in balancing redox equations \\
\hline 5. & Describe the inter-conversion of chemical energy and electrical energy in redox reactions. \\
\hline 6. & Describe and explain the functions of a simple electrochemical cell. \\
\hline 7. & Explain some applications of electrochemical cells. \\
\hline 8. & Explain the operation of electrolytic cells. \\
\hline 9. & Illustrate the electrolysis of brine experimentally. \\
\hline 10. & Distinguish between electrolytic and electrochemical cells. \\
\hline
\end{tabular}

Table 2: Instructional Objectives on Electrochemistry (MoE, 2010)

Students' misconceptions were searched from chemistry literature. The questions of the test were developed according to these misconceptions and the curriculum instructional objectives.

The items were distributed among a set of subtopics of electrochemistry. The details are provided in Table 3. These subtopics form part of the syllabus of SHS chemistry in Ghana. Each item of the ECCT consisted of a question or statement followed by four options with three of them being distracters (misconception). The respondents were required to indicate the option that best represents their opinion on the question. The test covered the following subtopics in electrochemistry. 


\begin{tabular}{|cl|c|c|}
\hline \multicolumn{1}{|c|}{ Subtopics/ concepts } & Items & Number of Items \\
\hline 1. & Oxidation and reduction & $11,12,16,18$ & 4 \\
\hline 2. & Electrochemical cell & 3,6 & 2 \\
\hline 3. & Electrolytic cell & $5,8,13$ & 3 \\
\hline 4. & Placement of electrodes & $1,2,9$ & 3 \\
\hline 5. & Direction and flow of electrons & 10 & 1 \\
\hline 6. & Function of salt bridge & 7 & 1 \\
\hline 7. & Direction of ions flow & 4 & 1 \\
\hline 8. & Writing half reactions & 17 & 1 \\
\hline 9. & Balancing redox reactions & 19,20 & 2 \\
\hline 10. & Electrode potentials & 14,15 & 2 \\
\hline
\end{tabular}

Table 3: Subtopics, Items and Number of Items Making the ECCT

A correct answer to a question attracted one mark, and an incorrect answer, attracted zero mark for that question. The total score for each of the pre-test and post-test was 20.

The scores were put into three categories according to the range of scores as in Table 4.

The percentage correct and incorrect responses of items to the ECCT were computed to determine the level of misconceptions held by students in electrochemistry. The percentage of incorrect response (\%IC) indicated the level of misconceptions held by the students on each item.

\begin{tabular}{|c|c|}
\hline Category & Range of Scores \\
\hline Sound Understanding (SU) & $12-20$ \\
\hline Partial Understanding (PU) & $6-11$ \\
\hline Misconception (MC) & $0-5$ \\
\hline
\end{tabular}

Table 4: Categories of Misconceptions

\subsection{Structured interview}

An individual, face-to-face structured interview was used to obtain qualitative data for the study. According to Neuman (2007), face-to-face interviews have the advantage of high response rate and permit the interviewer to observe non-verbal communication and use extensive probes. The interview protocol developed by Sanger and Greenbowe (1995) for galvanic and electrolytic cells was adapted. The instrument was modified to facilitate students understanding of the questions. The interview was recorded and transcribed immediately. For the purpose of confidentiality, each student who took part in the interview was given a unique code which was later used in the presentation and discussion of the results. For example, DSI01 represented a student from Damongo Senior High School coded 1. Also, GSI01 represented a student from Ghana Senior High School coded 1.

\subsection{Trustworthiness of the interview}

Member checks were used to ensure trustworthiness of the interview data. According to Guba and Lincoln cited in Shenton (2004) member checks is considered the single most important provision that can be made to bolster a study's credibility. Participants were asked to listen to the tape recordings and read the transcripts of the interviews in which they participated. The emphasis was on whether the participants consider that their words matched what they actually intended. It was also to ensure that the tape recorder used accurately captured participants' articulations.

The interview protocol and the transcripts were also given to peers, experience chemistry teachers and senior lecturers to check that the questions and responses were trustworthy. Samples of the transcripts were also given to two colleagues for analysis and coding. Their analysis and coding were then compared with that of the researcher to ensure trustworthiness.

\section{Results}

\subsection{Results of the structured interview data}

The interview data was analyzed by the researcher using an inductive analysis procedure (Patton, 2002), in which data was carefully evaluated through repeated and independent readings of the transcripts to extract general themes. Content analysis was used to interpret responses. All answers provided by the 10 students were reviewed and classified by the researcher. The results of the interview were discussed under 5 areas; identifying cathode and anode in galvanic cells, understanding the functions of the salt bridge, understanding charge of the cathode and anode, identifying cathode and anode in electrolytic cells and understanding current flow in galvanic and electrolytic cells. The interview results showed that students in both groups held some alternative conceptions about electrochemistry.

\subsection{Identifying the Anode and Cathode of Galvanic Cells}

Students have many misconceptions about identifying the anode and the cathode. Two students out of the 10 interviewed correctly used the reactivity of the metals in the electrochemical series to determine or assign anode and cathode. This is showed in the following extract: 
- Researcher: How will you determine which electrode is the anode and which is the cathode?

- GSI02: ...you consider the reactivity of the metals.... zinc is above copper in the activity series.... the one that is above the other is the anode......it means it has a higher concentration of electrons......electrons flow from the anode to the cathode. Copper is the cathode .... That is, it accepts electrons.

- GSI04: you consider the two elements....... their positions in the electrochemical series......the one on top will loss electrons and becomes the anode......and the one below accepts electrons and becomes the anode.

Four students (40\%) used the charge/ signs of the electrodes to identify the anode and cathode. This is supported by the following explanations:

- Researcher: How will you determine which electrode is the anode and which is the cathode?

- DSI04: The zinc is the anode.... because it is the negative electrode... and the copper is the cathode because it is the positive electrode.

- DSI05: You look at the charge...the anode is always negative and the cathode is positive.

- DSI09: Looking at the diagram...... Zinc is anode and copper is cathode..... The zinc is positive acceptor and the copper is negative acceptor.

- GSI03: The zinc is the anode....... because it has a positive charge. The copper is the cathode because it has a negative charge.

Some students (10\%) also think that the anode is always on the left and the cathode on the right. Also, $20 \%$ of the students interviewed said that the anode is where oxidation occurs and the cathode is where reduction occurs. This is indicated in the following extract:

- Researcher: How will you determine which electrode is the anode and which is the cathode?

- DSI01: The left-hand side is the anode and the right-hand side is the cathode... the anode transfers electrons into the cathode by force so that the cathode is negative.

- GSI05: the anode is where oxidation takes place.... therefore, losses electrons ....and the cathode is where reduction takes place ........the cathode gains electrons.

- GSI01: Zinc is the anode.........since it is oxidized......and copper is the cathode since reduction occurs there. One student (10\%) said that $\mathrm{Zn}$ is anode because it losses electrons and $\mathrm{Cu}$ is cathode because it gains electrons. This is what he had to say:

- DSI03: The zinc electrode is the anode because it loses electrons and the charge is negative... and the copper is the cathode because it gains electrons and the charge is positive.

\subsection{Functions of the salt bridge}

Four students (40\%) correctly stated that the function of the salt bridge is to maintain electrical neutrality. This is what they had to say:

- Researcher: What is happening in the solution? What does the salt bridge do?

- GSI04: the salt bridge completes the internal circuit and maintains electrical neutrality.

- DSI01: The solution will move from anode to cathode. The salt bridge maintains electrical neutralization.

- GSI01: the salt bridge.........it produces ions to maintain electrical neutrality.

- GSI05: the salt bridge produces ions and ensures neutrality between the two solutions......ions are in the same solution.

The function of the salt bridge is not clear to many students. Two Students (20\%) said that ions pass through the salt bridge to produce electricity. This is what they had to say:

- Researcher: What is happening in the solution? What does the salt bridge do?

- DSI05: The salt bridge is where the ions pass through to help to produce electricity.

- GSI02: ... the zinc ions oxidize the zinc metal to release electrons ........and the salt bridge when there is higher concentration of ions it........the ions will flow through the salt bridge .........so that it will become stable.

Students also have misconception that the salt bridge connects electrons from anode to cathode. And that the salt bridge transfers charges between the electrodes. This is supported by the following students' comments:

- Researcher: What is happening in the solution? What does the salt bridge do?

- DSI04: The salt bridge connects the electrons from cathode to anode.

- DSI03: ...The salt bridge is used for the transfer of charges to neutralize......

\subsection{Direction of Flow of Ions/ Charges in Electrochemical Cell}

Only one student out of the 10 interviewed (10\%) was able to tell correctly that cations move from anode to cathode and anions from cathode to anode.

Researcher: In what direction do the charges/ ions flow in this electrochemical cell to complete the circuit?

DSI05: It flows opposite......cations from anode to cathode and anions flow from cathode to anode.

Five students out of the 10 (50\%) were able to predict the direction of movement of charges/ions but could not tell which precise kind of ions, that is whether cations or anions. This is indicated in the following excerpt:

- Researcher: In what direction do the charges/ ions flow in this cell to complete the circuit?

- DSI09: The charges flow from anode to cathode.

- GSI01...charges flow from anode to cathode. 
- GSI03: the ions flow ...anions flow from anode to cathode. Cations flow from cathode to anode. The anode is positive and the cathode is negative.

- GSI04: cations flow from cathode to anode and anions flow from anode to cathode.

- GSI05: charges flow from left to right....... anions flow from left to right and electrons move from right to left.

- DSI04: The charges flow from left to right......Anions flow from left to right and cations from right to left.

- DSI03: Charges flow from cathode to anode............cations will flow to the anode and anions to the cathode.

Two students of the 10 said that charges flow from left to right. They could not tell to which electrode. This shows that students had no concrete understanding of the movement of ions in an electrochemical cell. This is supported by the following students' comments:

- GSI05: charges flow from left to right....... anions flow from left to right and electrons move from right to left.

- DSI04: The charges flow from left to right......Anions flow from left to right and cations from right to left.

\subsection{Reactions Occurring at the Cells}

Three students representing 30\% were able to correctly tell the reactions taking place at each half-cell. In both galvanic and electrolytic cells oxidation occurs at the anode and reduction occurs at the cathode. The responses revealed that very few students have this understanding. Students also stated redox reaction without specifically stating the part of redox reaction.

Researcher: What reactions are taking place in each cell?

- GSI01: ...redox reactions...oxidation occurs at the anode and reduction at the cathode.... the anode is negative and the cathode is positive.

- GSI02: zinc is oxidized at the anode. At the cathode copper is reduced. The reactions occurring are......

- $\mathrm{Zn}(\mathrm{s}) \rightarrow \mathrm{Zn}^{2+}(\mathrm{aq})+2 \mathrm{e}^{-}$(oxidation) and $\mathrm{Cu}^{2+}(\mathrm{aq})+2 \mathrm{e}^{-} \rightarrow \mathrm{Cu}(\mathrm{s})$ (reduction). The anode is negative and the cathode is positive.

- GSI04...oxidation at the anode and reduction at the cathode....... the anode is negative and the cathode is positive.

The remaining students representing $70 \%$ could not tell the kind of reactions taking place at each cell. They however cited various incorrect chemical reactions. Only 1 student of the remaining had no idea of the kind of chemical reaction taking place at each cell. This is indicated in the following dialogue:

Researcher: What reactions are taking place in each cell?

- DSI01:...the first is a reaction...neutralization reaction.

- DSI05: The reaction...chemical reaction e.g. zinc plus......

- DSI09: Chemical reactions...zinc and copper.

- DSI04: Zinc and copper reaction.

- DSI03: Electrochemical reactions............

- GSI03: no idea

- GSI05: ......chemical reactions......electrochemical reactions. The anode is negative and the cathode is positive.

Common student misconceptions were identified from analysis of the individual structured interviews. The misconceptions are summarized in Table 5.

\begin{tabular}{|l|l|}
\hline \multicolumn{2}{|l|}{ Misconceptions } \\
\hline Galvanic Cell \\
\hline 1 & The left-hand side is the anode and the right-hand side is the cathode. \\
\hline 2 & The current produced will pass through the salt bridge and the go to the voltmeter. \\
\hline 3 & The current in electrochemical cell is produced by bringing two half-cells together. \\
\hline 4 & Current is produced by the movement of charges through the salt bridge. \\
\hline 5 & Current is produced by the transfer of charges from anode to cathode. \\
\hline 6 & The salt bridge is used for the transfer of charges for neutralization. \\
\hline 7 & The salt bridge maintains electrical neutralization. \\
\hline 8 & The salt bridge connects the electrons from cathode to anode. \\
\hline 9 & The salt bridge is where the ions pass through to help to produce electricity. \\
\hline 10 & In electrochemical cell charges flow from cathode to anode \\
\hline 11 & In electrochemical cell the anions flow from anode to cathode. \\
\hline 12 & In electrochemical cell the charges flow from left to right. \\
\hline 13 & Anions flow from left to right and cations from right to left. \\
\hline 14 & The charges flow from anode to cathode. \\
\hline 15 & Cations flow from cathode to anode and anions flow from anode to cathode. \\
\hline
\end{tabular}




\begin{tabular}{|c|c|}
\hline \multicolumn{2}{|c|}{ Misconceptions } \\
\hline \multicolumn{2}{|c|}{ Electrolytic Cell } \\
\hline 1 & In an electrolytic cell the left-hand side is the anode and the right-hand side is the cathode. \\
\hline 2 & In an electrolytic cell the anode is negative electrode and the cathode is positive electrode. \\
\hline 3 & $\begin{array}{c}\text { The left-hand side is anode because it is positive and the right-hand side is cathode because it is } \\
\text { negative. }\end{array}$ \\
\hline 4 & $\begin{array}{l}\text { In an electrolytic cell the negative terminal of the battery is the anode and the positive terminal } \\
\text { is the cathode. }\end{array}$ \\
\hline 5 & In electrolytic cell the metal which easily discharges electrons is the cathode. \\
\hline 6 & In an electrolytic cell cations flow from anode to cathode and anions flow from cathode to anode. \\
\hline 7 & In an electrolytic cell cations flow to the anode and anions flow to the cathode \\
\hline 8 & In an electrolytic cell anions flow from anode to cathode. \\
\hline
\end{tabular}

Table 5: Misconceptions Identified from the Interview Data

\subsection{Categories of misconceptions from the students test scores on ECCT}

Students' scores in the ECCT were put into three categories according to score ranges. The categories are: sound understanding (SU) [12-20], partial understanding (PU) [6-11] and misconception (MC) [0-5]. Table 6 shows the categories of misconceptions held by students in the experimental and control group before the intervention.

\begin{tabular}{|c|c|c|c|c|}
\hline Test & Group & MC & PU & SU \\
\hline Pre-test & EG & $26(50.9 \%)$ & $25(49.1 \%)$ & 0 \\
\hline Pre-test & CG & $33(63.5 \%)$ & $19(36.5 \%)$ & 0 \\
\hline
\end{tabular}

Table 6: Categories of misconceptions held by students

The results show that for both experimental and control groups no student had sound understanding of the electrochemistry concepts tested. This suggests that students had difficulties in understanding the concepts in electrochemistry. In the pretest, $26(50.9 \%)$ students of the experimental group had misconceptions and $25(49.1 \%)$ students had partial understanding. Also, in the pre-test, 33 (63.5\%) students of the control group had misconceptions and 19 (36.5\%) students had partial understanding. In all, more students in the control group had misconceptions than in the experimental group.

\subsection{Percentage correct responses to pre-test items of ECCT}

The percentage correct and incorrect responses of items to the ECCT were computed to determine the level of misconceptions held by students in electrochemistry. The percentage of incorrect response (\%IC) indicated the level of misconceptions held by the students on each item. Table 7 shows the percentage of correct and incorrect responses of the experimental and control groups before the intervention.

\begin{tabular}{|c|c|c|c|c|c|c|}
\hline \multicolumn{7}{|c|}{ Pre-test } \\
\hline \multicolumn{2}{|c|}{ Control group } & \multicolumn{3}{|c|}{ Experimental group } \\
\hline Item & $\mathrm{N}$ & $\% \mathrm{CR}$ & $\% \mathrm{IC}$ & $\mathrm{N}$ & $\%$ CR & $\%$ IC \\
\hline 1 & 52 & 51.9 & 48.1 & 51 & 60.8 & 39.2 \\
\hline 2 & 52 & 15.4 & 84.6 & 51 & 9.80 & 90.2 \\
\hline 3 & 52 & 23.1 & 76.9 & 51 & 21.6 & 78.4 \\
\hline 4 & 52 & 23.1 & 76.9 & 51 & 27.5 & 72.5 \\
\hline 5 & 52 & 32.7 & 67.3 & 51 & 43.1 & 56.9 \\
\hline 6 & 52 & 17.3 & 82.7 & 51 & 5.90 & 94.1 \\
\hline 7 & 52 & 42.3 & 57.7 & 51 & 11.8 & 88.2 \\
\hline 8 & 52 & 50.0 & 50.0 & 51 & 43.1 & 56.9 \\
\hline 9 & 52 & 15.4 & 84.6 & 51 & 3.90 & 96.1 \\
\hline 10 & 52 & 63.5 & 36.5 & 51 & 41.2 & 58.8 \\
\hline 11 & 52 & 13.5 & 86.5 & 51 & 7.80 & 92.2 \\
\hline 12 & 52 & 34.6 & 65.4 & 51 & 43.1 & 56.9 \\
\hline 13 & 52 & 46.2 & 53.8 & 51 & 66.7 & 33.3 \\
\hline 14 & 52 & 40.4 & 59.6 & 51 & 23.5 & 76.5 \\
\hline 15 & 52 & 57.7 & 42.3 & 51 & 17.6 & 82.4 \\
\hline 16 & 52 & 28.8 & 71.2 & 51 & 29.4 & 70.6 \\
\hline 17 & 52 & 61.5 & 38.5 & 51 & 49.0 & 51.0 \\
\hline 18 & 52 & 15.4 & 84.6 & 51 & 33.3 & 66.7 \\
\hline 19 & 52 & 71.2 & 28.8 & 51 & 62.7 & 37.3 \\
\hline 20 & 52 & 40.4 & 59.6 & 51 & 45.1 & 54.9 \\
\hline
\end{tabular}

Table 7: Percentage Correct and Incorrect Responses (ECCT) Of Experimental and Control Group before the Intervention 
$\mathrm{CR}=$ Correct Response, $\mathrm{IC}=$ Incorrect Response

In the control group, the percentage of correct responses in the pre-test ranged from 13.5\% (item 11) to $71.2 \%$ (item 19). It was observed that the percentage of correct responses of items $2,3,4,5,6,9,11,16$ and 18 were 32.7\% and below. Also, in the experimental group, the percentage of correct responses in the pre-test range from $3.9 \%$ (item 9 ) to $66.7 \%$ (item 13). It was observed for questions $9,6,11,2,3,14,7,15,16$ and 18 of the pre-test by the experimental group that the percentages of correct responses were $33.3 \%$ and below. It was found out that these questions were related to placement of anode and cathode in electrochemical cell (items 2, 9) $(9.8 \%$ and $3.9 \%$ respectively), functions of the salt bridge (item 7) [11.8\%], oxidizing and reducing agents (item 11) [7.8\%], using reactivity of metals to place anode and cathode (item 15) [17.6\%], oxidation and reduction in terms of electron transfer (item16) [29.4\%], oxidation and reduction in terms of change in oxidation number (item 18) [33.3\%], reactions occurring at the electrodes (item 3) [21.6\%]. Students also have misconceptions regarding placement of anode and cathode (items 2 and 9). Many students had the misconception that the anode is always on the left and the anode on the right.

\subsection{Percentage of correct responses on post-test items of the ECCT}

The proportions of correct responses and alternative conceptions were examined by performing item analysis of the ECCT items for both experimental and control groups after the intervention. Many students after the intervention failed to develop a scientifically acceptable understanding of the concepts in electrochemistry. Table 8 shows percentage of correct and incorrect responses of the ECCT of the experimental and control group after the intervention.

\begin{tabular}{|c|c|c|c|c|c|c|}
\hline \multicolumn{7}{|c|}{ Post-test } \\
\hline & \multicolumn{3}{|c|}{$\begin{array}{c}\text { Experimental } \\
\text { Group }\end{array}$} & \multicolumn{3}{c|}{ Control Group } \\
\hline Item & $\mathrm{N}$ & $\%$ CR & $\%$ IC & $\mathrm{N}$ & $\%$ CR & \%IC \\
\hline 1 & 51 & 70.6 & 29.4 & 52 & 57.7 & 42.3 \\
\hline 2 & 51 & 29.4 & 70.6 & 52 & 13.5 & 86.5 \\
\hline 3 & 51 & 15.7 & 84.3 & 52 & 23.1 & 76.9 \\
\hline 4 & 51 & 29.4 & 70.6 & 52 & 26.9 & 73.1 \\
\hline 5 & 51 & 54.9 & 45.1 & 52 & 51.9 & 48.1 \\
\hline 6 & 51 & 13.7 & 86.3 & 52 & 19.2 & 80.8 \\
\hline 7 & 51 & 31.4 & 68.6 & 52 & 28.9 & 71.1 \\
\hline 8 & 51 & 64.7 & 35.3 & 52 & 53.8 & 46.2 \\
\hline 9 & 51 & 25.5 & 74.5 & 52 & 13.5 & 86.5 \\
\hline 10 & 51 & 49.0 & 51.0 & 52 & 55.8 & 44.2 \\
\hline 11 & 51 & 7.8 & 92.2 & 52 & 17.3 & 82.7 \\
\hline 12 & 51 & 35.3 & 64.7 & 52 & 23.1 & 76.9 \\
\hline 13 & 51 & 39.2 & 60.8 & 52 & 51.9 & 48.1 \\
\hline 14 & 51 & 41.2 & 58.8 & 52 & 46.2 & 53.8 \\
\hline 15 & 51 & 43.1 & 56.9 & 52 & 46.2 & 53.8 \\
\hline 16 & 51 & 29.4 & 70.6 & 52 & 34.6 & 65.4 \\
\hline 17 & 51 & 47.1 & 52.9 & 52 & 59.6 & 40.4 \\
\hline 18 & 51 & 33.3 & 66.7 & 52 & 19.2 & 80.8 \\
\hline 19 & 51 & 74.5 & 25.5 & 52 & 80.8 & 19.2 \\
\hline 20 & 51 & 43.1 & 56.9 & 52 & 51.9 & 48.1 \\
\hline
\end{tabular}

Table 8: Percentage Correct and incorrect Responses (ECCT) of Experimental and Control Group

After the intervention

$\mathrm{CR}=$ Correct Response, $\mathrm{IC}=$ Incorrect Response

The results showed that the percentage of correct responses to some questions were lower than other questions. In the experimental group, the percentage of correct responses ranged from 7.8\% (item 11) to $70.6 \%$ (item 1), but in the control group, the percentage of correct responses ranged from 13.5\% (items 2 and 9) to 80.0\% (item 19). It was observed in questions 2,3,6,7,9,11,16, and 18 of the post-test of the experimental group that the percentage of correct responses were $31.4 \%$ and below. When these questions were examined in terms of their content areas, it was found that they were related to placement of anode and cathode in electrochemical cell (items 2, 9) [29.4 \% and 25.5\%], functions of the salt bridge (item 7) [31.4\%], oxidizing and reducing agents (item 11) [7.8\%], oxidation and reduction in terms of electron transfer (item 16) [29.4\%], and oxidation and reduction in terms of change in oxidation number (item 18) [33.3\%].

Also, the percentage of correct responses of items 2, 3, 4,6,7,9,11,12,16 and 18 of the control group were 34.6\% and below. These results showed that the percentage of correct responses of some items increased in the post-test after the treatment (items $1,2,4,5,6,7,8,9,10,14,15$ and 19). This meant that the conceptual change text is effective in eliminating some misconceptions. Few items (11 and 16) did not increase after the intervention, which suggested that some misconceptions are difficult to change. 


\subsection{Common Misconceptions held by Students from the ECCT Items}

Analysis of students' responses to items on the ECCT revealed some misconceptions held by students after the intervention.

Table 9 shows the percentage of common misconceptions held by students from the ECCT after treatment.

\begin{tabular}{|c|c|c|c|c|c|}
\hline \multirow[t]{3}{*}{$\mathbf{S} / \mathbf{n}$} & \multirow[t]{3}{*}{ Misconception } & \multicolumn{4}{|c|}{ Group } \\
\hline & & \multicolumn{2}{|c|}{ CG } & \multicolumn{2}{|c|}{ EG } \\
\hline & & \%IC & $\% \mathrm{CR}$ & $\% \mathrm{IC}$ & $\% \mathrm{CR}$ \\
\hline 1 & $\begin{array}{l}\text { In an electrochemical cell oxidation occurs at the cathode and } \\
\text { reduction at the anode }\end{array}$ & 34.6 & 65.4 & 25.5 & 74.5 \\
\hline 2 & The cathode in an electrochemical cell always go on the left. & 17.3 & 82.7 & 17.6 & 82.4 \\
\hline 3 & The cathode in an electrochemical cell always go on the right. & 51.9 & 48.1 & 35.3 & 64.7 \\
\hline 4 & $\begin{array}{c}\text { The cathode in an electrochemical cell always go with the } \\
\text { reducing agent. }\end{array}$ & 17.3 & 82.7 & 17.6 & 82.4 \\
\hline 5 & Nothing will happen at the surface of inert electrodes. & 23.1 & 76.9 & 15.7 & 84.3 \\
\hline 6 & In an electrochemical cell anion move from anode to cathode & 36.5 & 63.5 & 41.2 & 58.8 \\
\hline 7 & In an electrochemical cell anion move from anode to salt bridge & 19.2 & 80.8 & 15.7 & 84.3 \\
\hline 8 & $\begin{array}{l}\text { In an electrochemical cell anion move from salt bridge to } \\
\text { cathode }\end{array}$ & 17.3 & 82.7 & 13.7 & 86.3 \\
\hline 9 & The function of the salt bridge is to allow electron flow. & 46.2 & 53.8 & 54.9 & 45.1 \\
\hline 10 & The function of the salt bridge is to allow proton flow. & 3.80 & 96.2 & 5.90 & 94.1 \\
\hline 11 & $\begin{array}{c}\text { The function of the salt bridge is to complete the circuit by } \\
\text { providing electrons }\end{array}$ & 21.2 & 78.8 & 7.80 & 92.2 \\
\hline 12 & $\begin{array}{c}\text { In an electrolytic cell oxidation occur at the cathode and } \\
\text { reduction occur at the anode. }\end{array}$ & 46.2 & 53.8 & 33.3 & 66.7 \\
\hline 13 & The anode in an electrochemical cell always go on the left. & 40.4 & 59.6 & 41.2 & 58.8 \\
\hline 14 & The anode in an electrochemical cell always go on the right. & 26.9 & 73.1 & 13.7 & 86.3 \\
\hline 15 & $\begin{array}{c}\text { The anode in an electrochemical cell always go with the } \\
\text { oxidizing agent. }\end{array}$ & 19.2 & 80.8 & 19.6 & 80.4 \\
\hline 16 & $\begin{array}{c}\text { In an electrochemical cell electron move from one electrode to } \\
\text { the other through the salt bridge. }\end{array}$ & 34.6 & 65.4 & 41.2 & 58.8 \\
\hline 17 & $\begin{array}{l}\text { In an electrochemical cell electron move throughout the entire } \\
\text { system. }\end{array}$ & 5.80 & 94.2 & 5.90 & 94.1 \\
\hline 18 & $\begin{array}{l}\text { In an electrochemical cell the metals are connected through a } \\
\text { salt bridge. }\end{array}$ & 34.6 & 65.4 & 23.5 & 76.5 \\
\hline
\end{tabular}

Table 9: Percentage of Common Misconceptions (\%IC) held by Students in Control and Experimental Group on the ECCT after Treatment $\mathrm{CR}=$ Correct Response, $\mathrm{IC}=$ Incorrect Response

The results showed that there exists significant difference between the percentages of misconceptions of students in the experimental and control groups after treatment. This suggested that conceptual the change texts helped students to change their pre-existing conceptions or misconceptions for scientifically acceptable ones. The study also revealed that some misconceptions were held by a considerable number of students even after the instruction using conceptual change texts. The misconceptions numbered 1,3,6,9,12,13,16, and 18 were prevalent among the students in both groups. The most common misconception is that the function of the salt bridge is to allow electron flow (9), the anode in an electrochemical cell is always on the left (13), in an electrochemical cell electrons move from one electrode to the other through the salt bridge (16), in an electrochemical cell anions move from anode to cathode (6), the cathode in an electrochemical cell is always on the right (3), and in an electrochemical cell oxidation occurs at the cathode and reduction at the anode (1).Another common misconception held by students in both experimental groups and control groups is that, in an electrochemical cell the metals are connected through a salt bridge (18). The results also revealed that misconceptions 10 , 11 and 17 are held by few students in both experimental and control groups. These misconceptions are: the function of the salt bridge is to allow proton flow (10), the function of the salt bridge is to complete the circuit by providing electrons (11), in an electrochemical cell electron move throughout the entire system (17). Few students held misconceptions 1, 3, 5, 7, 8, $11,12,14$, and 18 in the experimental group than in the control group. Also, few students held misconceptions 2, 4, 6, 9, $10,13,15$, and 17 in the control group than in the experimental group. Students still have some misconceptions even after the treatment. This confirms the assertion that some misconceptions are resistant to change. Bodner cited in Canpolat, Pinarbasi, Bayrakceken, and Geban (2006) confirmed that some misconceptions are resistant to instruction.

\section{Discussion}

The results from the interview showed that students had many misconceptions in electrochemistry especially on galvanic cells and electrolytic cells. Some students (10\%) think that the anode is always on the left and the cathode on the right. This confirms the findings of Sanger and Greenbowe (1997) who reported that students think the anode is always 
the electrode that appears on the left-hand side of a diagram and the cathode is always the electrode on the right. Students think that the identity of the anode and cathode depends on the physical placement of the half-cells. The source of the misconception is from the diagrams presented in the chemistry textbooks and teachers' diagrams during instruction.

Two students $(20 \%)$ of the students interviewed said that the anode is where oxidation takes place and the cathode is where reduction occurs. One student said that $\mathrm{Zn}$ is the anode because its losses electrons and $\mathrm{Cu}$ is cathode because it gains electrons. Students also have misconceptions concerning the function of the salt bridge. For example, students report that the salt bridge connects electrons from anode to cathode and that the salt bridge transfers charges between the electrodes. Two students (20\%) also said that ions passed through the salt bridge to produce electricity.

Only five students out of the 10 were able to predict the direction of movement of charges/ ions but failed to tell which precise kind of ions involved that is whether cations or anions. Two students out of the 10 also said that charges flow from left to right.

Seven of the students (70\%) out of the 10 could not tell the kind of reactions taking place in the set-ups. They however cited various incorrect chemical reactions (Table 10). One student said he had no idea of the kind of chemical reaction taking place at each electrode.

\begin{tabular}{|c|c|c|}
\hline Reaction & Number of Students & Percent (\%) \\
\hline Electrochemical & 2 & 20 \\
\hline Oxidation reduction & 3 & 30 \\
\hline Neutralization & 1 & 10 \\
\hline Zinc copper reaction & 1 & 10 \\
\hline Chemical reaction & 2 & 20 \\
\hline No idea & 1 & 10 \\
\hline
\end{tabular}

Table 10: Students Ideas of Reactions Occurring at the Electrodes

When students were asked how current is produced in an electrochemical cell, one student said that current is produced by the transfer of charges from anode to cathode. Three of the students (30\%) said that current is produced through the electrodes. One student also said that current is produced when the two half cells are joint together.

In identifying the anode and cathode in electrolytic cells, two students (20\%) said that the anode is the positive electrode and the cathode is the negative electrode. They could not give any reason for their explanation. Two students (20\%) said the anode is on the left-hand side and the cathode is on the right-hand side. Hamza and Wickman, (2007) made a similar observation that students think that the anode is always on the left and the cathode on the right. When students where asked if they know what happens at the anode and the cathode electrodes, Hamza and Wickman found that learners had misconception about the electrode and that learners seem to think that the cathode is always on the right and the anode on the left.

One student said oxidation occurs at the anode and reduction occurs at the cathode.

A major student misconception that Sanger and Greenbowe (1997) also identified pertains to electron flow through a cell. They found that many students believed that the electrons flow from "anode to the cathode along the wire and are then released into the electrolyte at the cathode, traveling through the electrolyte solution".

The findings of this study support previous research, for example Ndovu (2014) reported that learners think that ions move through the salt bridge from one half-cell to the other half-cell and that ions move from the salt bridge into the half-cells to ensure that no built-up of charge takes place at the electrodes. Rahayu, Treagust, Chandrasegaran, Kita \&Ibnu (2011) found that students have problems about the type of ions in the salt bridge that moved to the cathode and the anode in a voltaic cell.

Greenbowe and Sanger (1999) found that most students mistakenly identified the anode and cathode in galvanic cells according to the placement of the electrodes in diagrams in textbooks (the anode commonly depicted on the left and the cathode on the right). Again, Sanger and Greenbowe (1999) attribute some of these misconceptions to over simplification of electrochemical cell by teachers. An example of a simplification would be repeatedly illustrating a voltaic cell with the anode on the left side, inferring that the relative location of the electrode determines the nature of the particular oxidation (or reduction) reaction that occurs there.

Sanger and Greenbowe (1997) found that students often describe the movement of electrons in electrochemical cells as: electrons flowing from the anode to the cathode along the wire, entering the solution from the cathode, traveling through the solution and the salt bridge, and emerging at the anode to complete the circuit.

\section{Conclusion}

The results showed that students' misconceptions were centered on identifying cathode and anode in galvanic cells, understanding the functions of the salt bridge, understanding charge of the cathode and anode, identifying cathode and anode in electrolytic cells and understanding current flow in galvanic and electrolytic cells. It was found that students in both the experimental and control groups have some misconceptions about electrochemistry. Also, for both experimental and control groups no student had sound understanding of the electrochemistry concepts tested. This suggests that students had difficulties in understanding the concepts in electrochemistry. Thus, it behooves chemistry teachers to adopt conceptual change approaches to teaching chemistry concepts in order to make the learning of chemistry meaningful. There was significant difference between the percentage of misconceptions of students in the experimental and control groups after treatment. This suggested that conceptual change texts helped students to change 
their pre-existing conceptions or misconceptions for scientifically correct ones. Chemistry teachers should consider using conceptual change texts in teaching. Researchers have suggested that conceptual change texts could be combined with other constructivist teaching methods in teaching chemistry. The study also revealed that some misconceptions were held by a considerable number of students even after the instruction using conceptual change texts. This could be due to the fact that misconceptions are difficult to change. Traditional chemistry instruction alone is not enough to eliminate students' misconceptions. Therefore, teachers should consider the students' misconceptions and pre-existing knowledge when planning the instruction.

\section{References}

i. Akram, M., Bin Surif, J. \& Ali, M. (2014). Conceptual Difficulties of Secondary School Students in Electrochemistry. Journal of Asian Social Science. 10 (19), Retrieved from: http://dx.doi.org/10.5539/ass.v10n19p276 on 7th September, 2015. DOI:10.5539/ass. v10n19p276

ii. Balci, C. (2006). Conceptual Change Text Oriented Instruction to Facilitate Conceptual Change in Rate of Reaction Concepts. A Thesis Submitted to The Graduate School of Natural and Applied Sciences. In Partial Fulfillment of the Requirements for the Degree of Master of Science in Secondary Science and Mathematics Education October 2006.

iii. Canpolat, N., Pinarbasi, T., Bayrakceken, S., \&Geban, O. (2006). The Conceptual Change Approach to Teaching Chemical Equilibrium. Research in Science \& Technological Education, 24(2), pp. 217-235.

iv. Garnett, P. J., \& Treagust, D. F. (1992b). Conceptual Difficulties Experiences by Senior High School Students of Electrochemistry: Electrochemical (Galvanic) and Electrolytic Cells. Journal of Research in Science Teaching, 29, pp. 121-142.

v. Hamza, K. M. \& Wickman, P. O. (2007). Describing and Analyzing Learning in Action. An Empirical Study of the Importance of Misconceptions in Learning Science. Science Education. Retrieved from http:/ / www.interScience@willey.com/ on 4th November, 2015. DOI: 10.1002/ sce20233, 141-164.

vi. Huddle, P. A., White, M. D., \& Rogers, F. (2000). Using A Teaching Model to Correct Known Misconceptions in Electrochemistry. Journal of Chemical Education, 77 (1), pp.104-110.

vii. Levy, Y. \&. Ellis, T. J. (2011). A Guide for Novice Researchers on Experimental and Quasi-Experimental Studies in Information Systems Research. Interdisciplinary Journal of Information, Knowledge, and Management. Volume 6, pp. 151-60, 2011. Retrieved from: http

viii. Meyers, K. (2007). Examining How Teaching Strategies Alter the Misconceptions of Middle School Science Students. Education and Human Development Master's Theses. The College at Brockport. Paper 369.http:/ / digitalcommons.brockport.edu/ ehd theses

ix. Ndlovu, M. (2014). The Design of an Instrument to Measure Physical Science Teachers' Topic Specific Pedagogical Content Knowledge in Electrochemistry. A research project submitted to the Faculty of Science, University of the Witwatersrand in Partial fulfillment of the requirements for degree of Master of Science (Science Education). Retrieved on 25th August, 2015 from: www.wits.ac.za/ library

x. Neuman, W. L. (2007). Basics of Social Research: Qualitative and Quantitative Approaches (2nd ed). London: Pearson, Allyn and Bacon.

xi. Osterlund, L-L., \&Ekborg, M. (2009). Students' Understanding of Redox Reactions in Three Situations. Nordina, 5, p. 115-127.

xii. Ozkaya, A. R. (2002). Conceptual Difficulties Experienced by Prospective Teachers in Electrochemistry: Half-Cell Potential, Cell Potential, and Chemical and Electrochemical Equilibrium In Galvanic Cells. Journal of Chemical Education, 79 (6), pp.135-738.

xiii. Ozmen, H. (2004). Some Student Misconceptions in Chemistry: A Literature Review of Chemical Bonding. Journal of Science Education \& Technology, 13, pp.147-159.

xiv. Ozmen, H. (2004). Some Student Misconceptions in Chemistry: A Literature Review of Chemical Bonding. Journal of Science Education \& Technology, 13, pp.147-159.

xv. Ozmen, H. (2007). The Effectiveness of Conceptual Change Texts in Remediating High School Students' Alternative Conceptions Concerning Chemical Equilibrium. Asia Pacific Education, 8 (3), 413-425.

xvi. Read, J. R. (2004). Children's Misconceptions and Conceptual Change in Science Education. Retrieved from http:/ / acell.chem.usyd.edu.au/ Conceptual-Change.cfmon 5th November, 2015.

xvii. Sanger, M. J. and Greenbowe, T. J. (1999). "An Analysis of College of Chemistry Textbooks as Sources of Misconception and Errors in Electrochemistry." Journal of Chemical Education, 76(6), 853-860.

xviii. Sanger, M. J., \&Greenbowe, T. J. (1997b). Students' Misconceptions in Electrochemistry: Current Flow in Electrolyte Solutions and the Salt Bridge. Journal of Chemical Education, 74 (7), 819-23.

xix. Schmidt, H-J., Mahon, A., \& Harrison, A. G. (2007). Factors That Prevent Learning in Electrochemistry. Journal of Science Teaching, 44(2), pp. 258-283. Retrieved from http:// www.interScience@willey.com/ on 25 th October, 2015.

xx. Shenton, A. K. (2004). Strategies for Ensuring Trustworthiness in Qualitative Research Projects. Education for Information, 22, 63-75, p 63, IOS Press.

xxi. Sirhan, G. (2007). Learning Difficulties in Chemistry: An Overview. Journal of Turkish Science Education, 4 (2), September. Retrieved from http:/ / www.tused.org on $2^{\text {nd }}$ November, 2015.

xxii. Taber, K.S. \& Tan, K. C. D. (2011). The Insidious Nature of 'Hard-Core' Alternative Conceptions: Implications for the Constructivist Research Programme of Patterns in High School Students' and Pre-Service Teachers' Thinking About Ionization Energy. International Journal of Science Education, 33(2), 259-297. 
xxiii. Taha, H. (2014). The Effects of Inductive Teaching Methods in an Electrochemistry Class. The 2014 WEI International Academic Conference Proceedings Bali, Indonesia.

xxiv. Uzuntiryaki, E. (2003). Effectiveness of Constructivist Approach on Students' Understanding of Chemical Bonding Concepts. PhD Thesis. Middle East Technical University Secondary Science and Mathematics Education, Ankara 